\title{
Success Factors of Upgrade Programs of SMEs in a Changing Environment, Resources Dependency Perspective: The Case of Algeria
}

\author{
Boudjemaa Amroune ${ }^{1}$, Michel Plaisent ${ }^{2, *}$, Taieb Hafsi ${ }^{3}$, Prosper Bernard ${ }^{2}$, Cataldo Zuccaro ${ }^{2}$ \\ ${ }^{1}$ Faculty of Economics and Management, University Med BOUDIAF, Algeria \\ ${ }^{2}$ School of Management Sciences, University of Quebec in Montreal, Canada \\ ${ }^{3}$ HEC Montreal, Montreal Business School, University of Montréal, Canada
}

Copyright $\bigcirc 2017$ by authors, all rights reserved. Authors agree that this article remains permanently open access under the terms of the Creative Commons Attribution License 4.0 International License

\begin{abstract}
The SME sector is exposed to an arduous and fierce competition to the disadvantage of enterprises that are actually non-competitive. Therefore, the problems of SMEs in developing countries are rich and complex. Algeria isn't immune to these difficult conditions; the SME is exposed to an open and intense environment. Public authorities have developed and have been implementing upgrade programs to promote the SME sector. Thus, the study seeks to find the key success factors of upgrade programs, and explores the dimension of adaptation of SMEs in developing and emerging countries, Algeria is a practical case. The study is theoretical. It aims to determine a theoretical model on the success factors of upgrade programs. The research operates a diverse literature review in emerging and developing countries. To explain this research, we will use the theory of resources dependency. While exploring the literature on upgrade programs in emerging and developing countries; our research was able to theoretically identify different success factors of the upgrade programs. In addition, research has managed to develop a theoretical model on the success factors of the upgrade programs.
\end{abstract}

Keywords Success Factors, Upgrade Programs, Government Programs, Changing Environment, Adaptation, Resources Dependency Theory, Intangible and Tangible Resources, Emerging and Developing Countries, Algeria

\section{Introduction}

Small and medium-sized enterprises "SMEs" in the developing countries "DC" are challenged by political, economic, business instability and changing environment constantly [74]. The SME sector is exposed to an arduous and fierce competition to the disadvantage of enterprises that are actually non-competitive [61]. Therefore, the problems of SMEs in developing countries are rich and complex. In general, in all countries, regardless of their category (developed, emerging or in developing), SMEs are considered as engines of economic development and one of the main contributors to the creation of sustainable jobs and to increase added value [55].

Furthermore, although SMEs remain at the heart of economic development in developing countries, they have not fulfilled their anticipated objectives due to a number of known structural constraints, according to [11] entrepreneurs are still facing problems in any country. However, entrepreneurs in developing countries, including poor countries and countries in transition, have more problems [80]. Problems related to the creation and development of new businesses in transition economies, which refer to the former Soviet Union, in some countries of Eastern Europe, Southeast Asia and some African countries, are serious.

Reference [109] argues that enterprises in developing countries, including Indonesia, are facing tough and fierce competition. Similarly, in the Egyptian context, $[113,121]$ demonstrate that currently in a globalized economy system, the Egyptian manufacturing sector is facing a decline in the terms of trade. Also, the Egyptian economy suffers harsh international competitive pressures. Furthermore, in most developing countries, entrepreneurs face a volatile and highly bureaucratic environment. The laws governing private enterprise, particularly for business registration and tax systems, are very complex and difficult to understand [18]. Private property and contract rights are often poorly designed and implemented. As stated by [59], unfavorable institutional regulatory environment is often accompanied by additional expenditure for corruption.

With this in mind and through regard to the impact of the changing environment, Pierre-André Julien presents the 
changing context of SMEs in a globalized world as follows: "... the globalization movement, which has accelerated in the last decade, can be explained by the increase in trade not only in goods, but especially services, particularly in developing countries (...) this movement can affect dramatically SMEs by intensifying competition in all local markets and disrupting export markets [55]. In addition, the enterprise in developing countries is vulnerable to its environment. However, this environment is the source of scarce and critical tangible and intangible resources, according to [63].

The Algerian enterprise is not immune to this fact, after huge gains during the seventies and the first half of the eighties, planned Algerian economy is showing great signs of asphyxia due a sharp reversal of global external contingencies which only highlight the structural problems of the Algerian economy [5]. These circumstances have greatly influenced the public Algerian industry. These author mentions that the Algerian industry faced the worst conditions from foreign competition and will intensify further. Following this problematic, Algeria has begun a process of deindustrialization by the privatization of public enterprises and the dismissal of their employees [7].

As in developing countries, particularly in Algeria, upgrade or more generally the adaptation of SMEs are so far in a variation phase, this is according to the principle of [70] and our study opens a way to the selection phase. Thus, the objective of this study is the search of key success factors, and explores the dimension of adaptation of SMEs, mainly on the organizational plan, while studying the case of Algeria.

\section{Literature Review}

The upgrade is therefore an organizational change which aims to adapt the enterprise to its contextual environment, to ensure its performance and to promote its competitiveness. The upgrade is a driver mechanism of the adaptation process. The upgrade provides support for investment in productivity, business modernization and provision of sustainable growth over time. Thereby [5] define the upgrade program by adapting the structures, resources and SME management processes in order to improve its performance and to insert it into the arena of both domestic and international competitions.

In this study, we will use these two concepts: upgrade and adaptation to explain the process of rehabilitation of the enterprise to its immediate environment. To explain the upgrade concept in the adaptive component, a theoretical overview of the relationship between organizational change and adaptation is required. We also present the relationship between organizational change and performance of SME. In addition, to present the contribution of the resources dependency perspective for adaptation and explain the enterprise's performance, we will accomplish a literature review by presenting the key success factors of upgraded SMEs. This upgraded SMEs are beneficiaries of an upgrade program practically in developing countries. Finally, below, we will expose the preparation of our hypothesis and the formulation of our theoretical framework.

\subsection{Organizational Change and Adaptation}

The proponents of adaptation theory of Hrebiniak and Joyce [49] describe the adaptation via an organizational change. The aim of this organizational change is to align the capabilities of the organization to their environmental contingencies. Also, reference [72] defines adaptation as a revolutionary organizational change leading to a major transformation in the reorientation of the organization. In fact, the theoretical literature on organizational change implies that environmental changes lead to organizational changes [122]. Reference [71] described the environment as being composed of two distinct characteristics: 'the rate of change in terms of speed and volatility,' and the" unpredictability of change".

So while the environment has become more complex and evolving more rapidly, organizations were asked to interact with the environment through dynamic actions and effective strategies [95]. Reference [45] put forward a proposal to show that "any increase in the degree of environmental uncertainty (e.g. increased turbulence and heterogeneity) increases the pressure for change." In short, change efforts can be forced on an organization by the laws, regulations, customer requirements and other environmental factors [73]. In systems theory, [114] explained that the organization should be considered as an open system that interacts with the contextual environment in order to survive. In this sense, [44] stated, "It is then clear that the environment has a decisive influence on the ability of an organization to survive long term". So, organizations change in response to changes in their environment [93].

Reference [87] defines the change in the process that the organization uses to design, to implement and to evaluate appropriate initiatives. In fact, this process helps to meet the demands placed on them by the external environment. Thus, the need for change is often driven by a sense of emergency crisis as a means of survival of businesses, in terms of the leadership and the employee [1]. However, the change often occurs seemingly spontaneously, unexpectedly or urgently [67]. But it would be more convenient to think that change is expected from a deliberate process, from a consequence of conscious and reasoning activity and from a clear cause. The change is the result of a well-structured rational process and is translated into actions in the field [73].

Reference [88] argues that " the literature about organizational change and on management believes that organizational change is much discussed". Change 
involves doing different things. Some organizations treat change as accidental fact, radical changes or restructuring activities. But the author holds that organizational change is defined as "the activities of change that are intentional and directed towards a specific purpose". The fact remains that change is never easy because it implies a new model of power.

Reference [34] gave a more or less detailed definition. They said that the change has been variously classified, first as planned or as emergent, second as revolutionary or as evolutionary, third as rational or as chaotic, fourth as continuous or as episodic change, fifth as transactional or as transformational, and finally as adoptive or as adaptation. They explained that it can be understood in relation to its size and scope. This is can be recognized, of course, with three separate types of changes: development, transactional and transformational.

Reference [54] shows that, to further organizational changes, there are several factors that must be taken into account: the change planned or unplanned, change intentional or unintentional, change batch or continuous, change incremental or quantum leaps, change event or programed, and change transformation or transition. Understanding these factors is important for achievement of the successful implementation of a change. This is in terms of its effect on organizational performance.

\subsection{Organizational Change and Performance}

Management of change is recognized as one of the most difficult challenges for organization managers. Academics and practitioners have examined the management of change in organizations since the emergence of the Management Sciences [67]. They concluded that the central aim of developing a strategic change is to improve the effectiveness and organizational performance [97]. The expectation of this change is that increase competitiveness, optimizes organizational flexibility, improves product quality, reduces operating costs and maximizes organizational performance considerably $[22,67]$.

Reference [45] postulates a proposal to say that "a large gap between current performance and desired performance drives managers to find solutions that generally push to organizational change." Reference [20] shows that "poor performance leads to a decreased resistance to change, to a reduction of conflict and to increase in organizational innovation, etc.". The most obvious is that poor performance pushes managers to overcome resistance to change. The change offers a chance to do things differently, which could legitimize the actions of change that have been politically difficult [46].

Similarly, [45] put forward two proposals in which "a significant change in the performance of an organization, whether positive or negative, increases the pressure for change". Furthermore, they added that «a decline in the performance of an organization relatively to its competitors leads to more pressure for organizational change." Both studies of [31, 82] presented the organizational models of action in which a decline in performance pushes to a corrective management action. Consequently, these lead to major or minor changes.

Reference [95] confirms that change takes time, human effort, and tangible and intangible resources for its implementation. For conducting change activities, to retain competent employees so they can have job security and be encouraged to become change champions. The latter author argues that organizations should promote training and human resource development. He adds that organizations should invest more in the development of human resources to deal with the new organizational transitions. Therefore, in the next section, we hope to explain the contribution of resources dependency theory with the concept of adaptation and performance, like as the study of the following reference [100]. This explanation is going to use in the analysis organizational tangible and intangible resources.

\subsection{Contribution of the Dependency Theory towards Resources to Explain Adaptation Process}

The vulnerability of an organization to its environment comes from its need for resources: materials, human resources, capital, equipment, knowledge and markets for its products/services, etc. However, these resources are controlled by the organization's environment, which gives it power [48]. Some authors have developed alternative theories about corporate adaptations that give greater freedom to act as entrepreneurs [81]. These authors have developed over time the theory of resources dependence. This is a theory about rational adaptation of the enterprise. Reference [81] argues that this theory can be used to explain the stability and rational adjustment of the enterprise to its context. The theory of resource dependency notices a bidirectional relationship between businesses and the environment, unlike previous adaptation perspectives. According to these views, the environment can be customized to businesses, as organizations adapt to their environment.

However, references [24,108] argue that the environment is not given, but must be "adapted". This environmental perspective is a phenomenon that is perceived subjectively and socially, constructed rather than an objective reality. Reference [81] occupies a middle position between the deterministic environment and the prospect of the free will of the entrepreneur in adapting its business.

According to [102], this theory puts in evidence the need to adapt to the uncertainty of the environment and to address the problems of SMEs interdependencies and control of resource flows in two ways. Reference [89] explains that the enterprise can adapt its structures, values, products, etc. to avoid dependence on critical or scarce 
external resources. It can store, trying to control the terms of trade, to vertically integrate or diversify its alternative resource requirements.

References [48,100] argue that dependency theory regarding resources still leaves significant room for voluntary and rational adaptation of the enterprise to its environment and the role of its internal functioning. He also added that the management of dependence against the resources, required to identify and carefully monitor the environment, but also imagining solutions to rebalance the enterprise's power relative to other partners when the situation becomes unfavorable. The same author finally says, if all these methods fail, and being unable to act adequately on the environment, there is a final opportunity for the enterprise: change the environment of its business. This is why, by example, international SMEs change trade or country.

Reference [116] explains that the vulnerability of an enterprise facing its changing environment comes from its need for resources. The dependence that follows, gives power to the environment, particularly for developing countries that suffer from a deficiency in critical and scarce resources. The latter require of the enterprise, many requirements such as competitive prices, products and services that meet the needs, structures and effective organizational processes.

However, reference [81] adds that government funding of research and development, business start-up and growth of small and medium-sized enterprises, offer attempts to manage the dependency of the business in respect of these resources. However, dependence on the skills and knowledge can be managed by hiring managers or others, or working in competing enterprises. According to [81], managing resources dependency requires defining and carefully monitoring the environment, but also imagining solutions to rebalance the enterprise power over others.

An emerging SMEs, more than any other, suffer from environment. However, [24, 25] argue that it appears nevertheless that SMEs can act on their environment and not just be under pressure. First, when this environment is rich and complex, it can be a factor of development for SMEs capable of seizing opportunities. Second, SMEs should be aware of the importance of clusters and networks to emerge from its isolation. Many researchers in entrepreneurship emphasize the importance of a designer to be integrated into business networks in order to obtain scarce resources to support its business.

Reference [2] emphasizes that it is more important for the entrepreneur to ask the question, "who does he know? " Instead of " what does he know? ". For reference [76], "the competitiveness of a person is equal to what he knows multiplied by whom he knows." These practices are the main elements of the upgrade program; we question whether the adaptation would affect performance, knowing that adaptation is a goal to be achieved by the implementation of actions to upgrade the business.

\subsection{Adaptation and Enterprise Performance}

The ability of an organization to adapt is a catalyst for organizational change [42]. However, various research highlights that managers perceive change as difficult and risky. Change is risky and is associated with an increased threat of enterprise's survival [90, 115]. However, leaders, namely entrepreneurs have an interest in maintaining the status quo [35], even if they have an incentive to change their businesses, the turbulent external environment could discourage them. Moreover, to adapt the contextual environment to an enterprise, it could be a source of stress for the enterprise's internal adaptation [64].

For [78], adaptation of the enterprise to its environment involves the ability to overcome the dissident effects that occurred. The reason, [23] argues that because of inadequate of enterprise strategies or failure to integrate resources with environmental requirements. In fact, adaptation is the result of a deliberate strategy with proper planning of official or conceivable activities. These activities are applied to products, services, markets and management methods [91]. These authors show that enterprises which develop more adaptation capabilities, have adaptation strategy and adapt more over time, will demonstrate higher performance than those putting less emphasis on adaptation [122].

Reference [91] concluded that adaptation has implications on the performance of small businesses. Indeed, the tendency to adapt over time is positively associated with the growth of profits and sales or increased profits compared to major competitors. They add that the resources both tangible and intangible and related activities, contribute to adaptability. Similarly, high levels of adaptation, [110] found that adaptation alters the relationship between hostility of the environment and the performance of SMEs.

Reference [8] shows that adaptation is related to performance of the enterprise, because the adaptive behavior is a continuous series of evaluations and adjustments. Each action of the adaptation initiative should improve performance by some incremental maneuvers. Reference [96] demonstrates that the relationship between adaptability and performance in small businesses is nonlinear. They add that a very high or very low adaptive capacity tends to have a negative impact on performance. They also show that most enterprises which adapt, do not have a high performance. Also, in large enterprises, some researchers have suggested that this relationship may be nonlinear $[68,49]$.

Reference [96] reveals the gap between coping behavior and performance. They confirm that adaptation is not a constant; some enterprises are better suited than others for certain periods. Reference [91] reports that entrepreneur recognizes the need to constantly adapt their business elements. At the same time, the tendency to adapt varies among entrepreneurs and businesses. However, the major adjustment may take more time to produce lasting results than does the minor adaptation [91]. In order to perform 
effectively, [85] find that small businesses need to take more care to align their internal structure to the rate of change in their environment. These changes affect technology, because SMEs are able to adapt to a lower cost than large enterprises. Since the success is a dimension of performance measurement, we will present in the next part the key success factors for small and medium enterprises in developing and emerging countries.

\subsection{Success Factors for Upgraded SMEs in Developing and Emerging Countries}

SMEs in developing countries, particularly in transition countries, such as Algeria, managed to cross the transition through a massive change. The change mainly affected the enterprise itself and its contextual environment. These countries developed several governmental programs for deloppment of SMEs. These programs are commonly called upgrade programs for SMEs. The objective of these programs is to develop this business sector and to make it more efficient, flexible and competitive.

In Poland, Hungary and Romania, the authorities have facilitated the upgrade programs of the SMEs through the introduction of some factors, including economic, administrative and legal reforms. These measures have allowed private enterprises to place themselves in a very good competitive position [60]. Reference [104] added other factors for sector development of SMEs for these three countries, among others, initiatives regarding the elimination of the system of central planning, decentralization of decision-making for state enterprises, the adoption of incentives-oriented institutional innovation, market liberalization, the flexibility of fiscal control, the reorganization of public enterprises, price liberalization, open markets to foreign investment and development of adequate infrastructure.

Furthermore, to create a good business climate in the enterprise itself, other factors have allowed the SMEs to upgrade. At first, the Asian countries including Hong Kong, Japan, China, Malaysia, Korea, Taiwan, Thailand and Singapore have developed their SMEs by enhancing the entrepreneurial spirit. This was the miracle birth of Asian countries [101]. Entrepreneurial development as part of the upgrade program effects functions such as mastery of financial management, marketing development and provides training and advisory services in good financial practices. Similarly, in Poland, the demand for business skills such as marketing, advertising and accounting, that were previously not needed, are now used by all business sectors [1]. The inspirations of transition countries, such as Romania and Hungary, have reinforced these upgrade programs by training on management techniques used by SMEs [1].

Also, reference [1] found, in the Czech and Slovak Republics, that public authorities have developed training programs on the preparation of business plans, on the technical penetration to local and foreign markets, on the organization of work, on the management of production, on the management of human resources and also on the management accounting techniques.

In addition, the SME sector in Malaysia has experienced substantial development through the development of human resources. This capital is a key element in improving technological capabilities and entrepreneurial businesses. Similarly, the Government of Indonesia has initiated entrepreneurship support programs to improve innovation, productivity, product quality and skills of human resources [1]. India and Taiwan have blossomed in the activities of the upgrade of the SME sector while focusing particularly on promoting innovation, multifaceted support to entrepreneurs, provision of necessary financing in the various stages of the development of SMEs [103].

Reference [103] explained that the Malaysian government offers incentives in the form of grants and loans. This practice has been found also in Poland by providing capital investment at a low cost, through the provision of long-term credit financing options and tax deductions practices. These funds are intended for the improvement of products, development of production processes, certification of product quality, standardization of products, improvement of production management systems and modernization of producing means.

To realize the training programs of the human capital of the enterprise, a common practice was observed in all the above countries such as the creation of business incubators, technology centers, innovation centers, industrial parks and specialized bodies in the start-up of SMEs.. These organizations have been very supportive in the various activities of the upgrade programs.

\subsection{Hypothesis and Theoretical Model Formulations}

In fact, more explicitly, the upgrade program in emerging and developing countries, such as the program for Algerian SMEs, is composed of operational and strategic functions. Operational functions are necessary for the daily operation of the business [5]. Strategic functions give a competitive advantage to the enterprise. In this study, we focus on operational functions. These functions are composed by the tangible and intangible resources. For upgrade plan variables of the enterprise, we selected the tangible and intangible resources.

The enterprise's resources can be defined as the productive assets through which the activities are completed within the enterprise [66]. These resources have been classified into six strategic resources: physical, reputation, organizational, human, financial, intellectual and technological resources [84]. Intangible resources are scarce, specialized, and difficult to imitate $[13,27,29$, 125]. Theoretically, intangible resources are important factors for business success [27, 65]. Reference [106] confirms that the administrative management has a 
significant effect on the enterprise's performance.

Concerning the tangible resources, they include physical resources and the enterprise's financial resources $[39,126]$. Physical resources, specifically in the case of developing countries, are appropriate to adopt the definition of [39], which refers to the technological level of sophistication owned by enterprises such as: machinery, equipment, tools and technologies. Material resources are easily identified and evaluated [41]. Technology can generate an advantage in determining the competitive position of a firm [83]. It is considered as the main driver for the success of the enterprise, according to [97]. It is, in this sense, that the tangible resources in our research focuses on machinery, equipment and sophistication of the technology [56].

Intangible resources are often tacit and difficult to codify [26]. They are also likely to be acquired in imperfect markets- These intangible assets are difficult to acquire, develop and reproduce within an enterprise [52]. In a behavioral perspective, intangible resources focus on the characteristics of the organization such as strategy, organizational structure, management processes and business operations $[30,57,118]$. In this perspective, priority is placed on the production, dissemination and interpretation of information on customer requirements [51]. Indeed, the adoption of market direction for an enterprise improves the performance of the enterprise relative to its competitors [119]. Therefore, for the behavioral perspective and management process approach for intangible resources of this research, we adopt the management processes which are presented in the management of production, quality management of products/services, organizational management, financial management, human resource management and marketing management $[1,62,75,77,123,124]$.

References [32, 65, 117] argue that all resources are equally important in determining the enterprise's performance. The results also show that intangible resources are important determinants for the enterprise's success. Reference [111] argues that corporate resources explain the competitive advantage and enterprise performance. The enterprise's internal resources are a much more stable point to develop the business and are considered as the main source of profit.

Reference [56] has often emphasized the relevance of internal resources, especially as intangible resources like the determinants of business competitiveness [47]. In this perspective, intangible investments play an important role in achieving a privileged position in the market and ensure the performance of the enterprise in the long-term [112].

It is, from the above, that we advance our hypothesis on the case of developing and emerging countries, and particularly that of Algeria.

Hypothesis: The upgrade program, presented in tangible and intangible resources, has a positive effect on the enterprise's performance: the case of Algerian SMEs.

This hypothesis spreads the causal relationship between the variables of the upgrade program, presented in intangible and tangible resources, against items for measuring performance. The latter is measured by financial and non-financial items. Then, Figure 1 presents the theoretical model of this research.

Furthermore, reference [6] expresses that as for the Algerian SMEs, the upgrade program in the developing countries is composed of operational and strategic functions and operational functions are necessary for the daily operation of the company. However, the strategic functions give a competitive advantage to the company. In this study, we focused on operational functions. These are composed of tangible resources and intangible resources. Indeed, the company's resources can be defined as the productive assets through which the activities are performed within the company [66]. For upgrade program variables on the company's plan, we selected the tangible resources and intangible resources [5]. These resources have been classified into six strategic resources: physical, reputation, organizational, financial, human, intellectual and technological [84].

Intangible resources are scarce, specialized, difficult to trade and imitate $[13,27,50]$. Intangible resources focus on the characteristics of the organization such as strategy, organizational structure, management processes and business operations [118]. Theoretically, intangible resources are important for business success [27,65]. However, tangible resources in the case of developing countries include the financial and physical resources. These physical resources include machinery, equipment, tools and technologies [39]. 

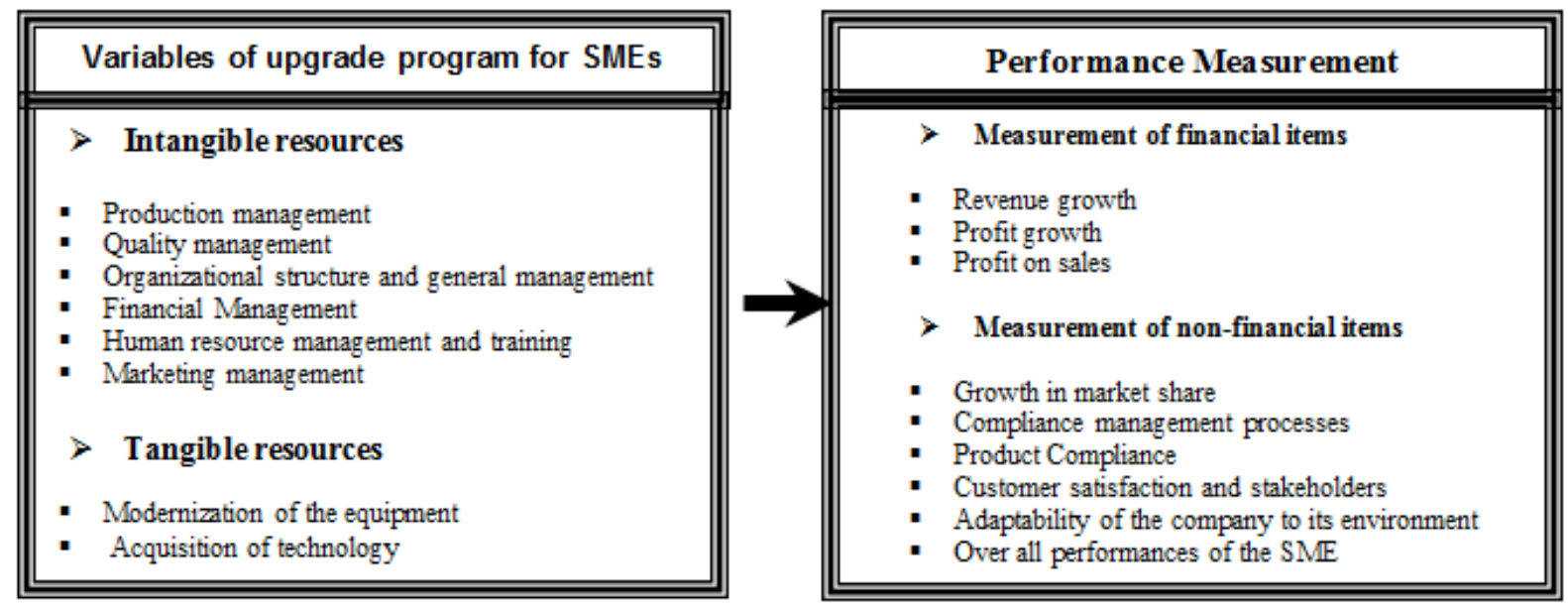

Figure 1. Theoretical model of research.

\section{Discussion}

The theoretical literature on organizational change considers that the environmental changes lead to organizational changes [120]. Both, proponents of the theory of adaptation [49], describe adaptation by organizational change in order to align the capabilities of the organization to environmental contingencies. Also, reference [72] defines adaptation as a revolutionary organizational change leading to a major transformation in the reorientation of the organization. Similarly, [70] consider that the adaptation process consists of three components: variation, selection and retention. In addition, the upgrade is an adaptive mechanism of the enterprise to its immediate environment.

The theory of [70] aims to segment and identify the different phases of the organizational adaptation process to its immediate environment. Indeed, the adaptation process is divided into three phases: the variation of practices, the selection of practices and the retention of practices that are successful.

The variation of practices is the development of these practices. The upgrade program is an example of a generation of these practices. These are borrowed from other programs and are borrowed from other contexts or outright are purely original practices.

For the selection of practices, this phase follows after the generation phase of these practices. This one is a phase of reflection, it relates to search for successful and unsuccessful practices. The objective is to further optimize the upgrade program or the adaptation process. So, this phase is part of our present research.

For retention, it is the improvement phase of the upgrade program, in this phase, we stop successful practices and we discard the unsuccessful practices or we're changing them.

In our present study, referring to the model of [70], we are now positioned in the selection component. Therefore, we have already identified theoretically the different practices of the upgrade program. We would like by this research identifying successful practices or success factors.

\section{Conclusions}

In this research, we provided an overview of the SME upgrade programs. This research used resource dependency theory to explain our theoretical framework. The research is purely theoretical, but we have developed a theoretical model that could be applied to all SMEs in developing countries, including countries that have implemented SME development programs.

The research is rich with academic references and professional references. The academic references allowed us to formulate the theoretical basis. However, professional references have allowed us to explore the best practices used for SME development, particularly in developing countries. For the writing of this research, we used a multitude of databases both English and French, which we subscribed to go deeper into the exploration of this very little known topic.

The limit of research was in the choice of theories that explain our research topic. Then, the challenge arises in the choice between the neo-institutional theory of organizations, the theory of contingencies or the theory of dependence on resources. Our research team has opted for the theory of dependence on resources. This choice is motivated by the following reason: in the day-to-day operation, the SME always remains vulnerable and with regard to internal resources of the enterprise and always dependent on existing resources in its business environment.

To test this model, so the next step is to make a quantitative empirical research select the success factors of the upgrade program in the context of developing and emerging countries. This future research wants first to develop a quantitative questionnaire that will be 
administered in the field.

\section{REFERENCES}

[1] M. Ajayi-Oluseyi, S. C. Morton. Exploring the Enablers of Organizational and Marketing Innovations in SMEs: Findings From South-Western Nigeria. SAGE Open, Vol. 1, No. 13, 2015.

[2] H. E. Aldrich, C. Zimmer. Entrepreneurship through social networks. The art and science sous la direction de D. SEXTON et R. SMILOR, pp. 3-23, M. A. Bellinger, Cambridge, 1986

[3] P. Amadieu, V. Jean-Laurent. Intangible Effort and Performance: The Case of the French Wine Industry. Agribusiness, Vol. 26, No. 2, 280-306, 2010.

[4] R. Amit, P. Schoemaker. Strategic assets and organizational rent. Strategic Management Journal, Vol. 14 No. 1, 33-46, 1993.

[5] B. Amroune. Upgrade programs of Algerian SMEs. Academic presses Francophone, Saarbrucken, Germany, 2016.

[6] B. Amroune. Impact of upgrade programs on the performance of SMEs in an open and intense environment: the case of Algeria. University of Quebec in Montreal, doctoral thesis, online available from http://www.archipel.uqam.ca/6744/

[7] B. Amroune. Building the performance of SMEs in emerging and developing countries: the case of Algeria. Publishing European University (UES), Saarbrucken, Germany, 2015.

[8] P. Andries, K. Debackere. Adaptation and Performance in New Businesses: Understanding the Moderating Effects of Independence and Industry. Small Business Economics, Vol. 29, 81-99, 2007.

[9] I. Anton, D. Danciu, C. Itu. The Role of SMEs in the Regional Redevelopment of Romania. The International Center for Entrepreneurial Studies, Bucharest University, Bucharest, Romania. 1996.

[10] M. Assarlind, I. Gremyr. Initiating quality management in a small company. The TQM Journal, Vol. 28. No. 2, 166-179, 2016.

[11] M. Ayyagari, A. Demirguc-Kunt, V Maksimovic. Who creates jobs in developing countries? Small Bus Econ, Vol. 43, 75-99, 2014.

[12] N. A. Aziz, N. M. Yassin. How Will Market Orientation and External Environment Influence the Performance among SMEs in the Agro-Food Sector in Malaysia. International Business Research, Vol. 3, No. 3, 154-164, 2010.

[13] J. B. Barney. Resource-based theories of competitive advantage: a ten year retrospective on the resource-based view, Journal of Management, Vol. 27, No. 6, 643-50, 2001.

[14] J. B. Barney. Organization culture: Can it be a source of sustained competitive advantage? Academy of Management Review, Vol. 11, 656-665, 1986.

[15] J. B. Barney. Gaining and Sustaining Competitive Advantage. Reading, MA: Addison-Wesley USA, 1996.

[16] [16] H. Bellihi, M. Bazi. Role of SMES in the economic and social development: case of terror products in Souss Massa Draa region (Morocco). Economic and Social Development, 7th International Scientific Conference, New York City, 2015.

[17] S. Bennaceur, A. Ben Youssef, S. Ghazouani, H. M'henni, L. Achy, Y. Benabdallah, M. Omran. Evaluation des politiques de Mise à niveau des entreprises de la rive sud de la méditerranée : les cas de l'Algérie, l'Égypte, le Maroc et la Tunisie. FEMISE Research Programme No. FEM31-05. 2007.

[18] C Benzing., H. M. Chu, O. Kara. Entrepreneurs in Turkey: A Factor Analysis of Motivations, Success Factors, and Problems. Journal of Small Business Management, Vol. 47, No. 1, 58-92, 2009.

[19] L. J. Bourgeois. Strategy and environment: A conceptual integration. Academy of Management Review, Vol. 5, No. 1, 25-39, 1980.

[20] K. Cameron, M. Kim, D. Whetten. Organizational effects of decline and turbulence. Administrative Science quarterly, Vol. 32, 222-240, 1987.

[21] F. Castilla-Polo, D. Gallardo-Vázquez. The main topics of research on disclosures of intangible assets: a critical review", Accounting, Auditing \& Accountability Journal, Vol. 29 No. 2 323-356, 2016.

[22] E. G. Ceptureanu. Reactions to Change in Romanian SMEs. Review of International Comparative Management, Vol. 16, No. 1, 2015.

[23] B. S. Chakravarthy. Adaptation: A promising metaphor for strategic management. Academy of management review, Vol. 7, 35-44, 1982.

[24] J. Child. Organization, structure, environment and performance: The role of strategic choice Sociology, Vol. 6, No. 1, 1-22, 1972.

[25] J. Child. Strategic choice in the analysis of action, structure, organizations and environment: Retrospect and prospect. Organization studies, Vol. 18, No. 1, 43-76, 1997.

[26] K. R. Conner, C.K. Prahalad. A resource-based theory of the firm: knowledge versus opportunism. Organization Science, Vol. 7, 477-501, 1996..

[27] T. Conner. The resource-based view of strategy and its value to practicing managers. Strategic Change, Vol. 11, 307-16, 2002.

[28] I. D. Coserin, V. C. Coserin, P. Coserin. The upsurge of hotels' strategic competition as per the E.U. integration. Global Conference on Business and Finance Proceedings, Vol. 7, No. 2, 633-637, 2012.

[29] V. Costa, R. Fernández, C Fernández-Jardon, Dorrego P. Critical elements for product innovation at Portuguese innovative SMEs: an intellectual e capital perspective. Knowledge Management Research \& Practice, Vol. 12, 322-338, 2014. 
[30] M. Crema, A Nosella. Intangible Assets Management and Evaluation: Evidence from SMEs. Engineering Management Journal, Vol. 26, No. 1, 2014.

[31] R. Cyert, J. March. A behavioral theory of the firm. Englewood Cliffs, NJ: Prentice-Hall. Pays, 1963.

[32] A. Daou, E. Karuranga, Z. Su. Towards a better understanding of intellectual capital in Mexican SMEs. Journal of Intellectual Capital, Vol. 15 No. 2, 316-332, 2014.

[33] H. Darja, M Březinová, P. Řehoř, V. Doležalová. Management of human resources in SMES. An Enterprise Odyssey. International Conference Proceedings, 2014.

[34] G. A De Waal, P. Knott. Innovation tool adoption and adaptation in Small technology-based firms. International Joumal of Innovation Management, Vol. 17, No. 3, 2013.

[35] P. J. Dimaggio, W. W Powell. The Iron Cage Revisited: Institutional Isomorphism and Collective Rationality in Organizational Fields. American Sociological Review, Vol. 48, 147-160, 1983.

[36] M. El-Shobery, M. El-Iskandrani, M. Hegazy. Improving Organizational Performance of Small and Medium Enterprises in Egypt through Promoting the Human Factors in quality Management Systems. International Journal of Business and Management, Vol. 5, No. 6, 2010.

[37] N. Finstad. The rhetoric of organizational change. Human Relations, Vol. 51, No. 6, 717-40, 1998.

[38] S. A. García, D. C. Popescu, I. A. Ciocârlan-Chitucea, D. P Oana How to Improve Small and Medium-Sized Enterprises Profitability by Practicing an Efficient Human Resources Management. Theoretical and Applied Economics, Vol. 18, No. 1, 49-64, 2011.

[39] R. M. Grant. Contemporary Strategy Analysis: Concepts, Technique, Applications, 4th ed., Blackwell Publishers, Cambridge, M. A., England, 2002.

[40] R. M. Grant. Contemporary strategy analysis: concepts, techniques, and applications. Cambridge, Black-well Publishers, England, 1991.

[41] R.M. Grant. Contemporary Strategy Analysis: Concepts, Technique, Applications, 2nd ed., Blackwell, Publishers, Cambridge, MA., England, 1995.

[42] R. Greenwood, A. Hinings. Understanding radical organization change: Bridging together the old and the new institutionalism. Academy of Management Review, Vol. 21, 1022-1054, 1996.

[43] M, Grimaldi, M. Greco, L. Cricelli. Perceived benefits and costs of intellectual capital in small family firms. Journal of Intellectual Capital, Vol. 17, No. 2, 351-372, 2016.

[44] T. Hafsi, B. Fabi. Les fondements du changement stratégique. Les Éditions Transcontinental in, Bibliothèques nationale du Québec, Canada, 1997.

[45] T. Hafsi, C. Demers. Comprendre et mesurer la capacité de changement des organisations. Les Editions Transcontinental in, Bibliothèques nationale du Québec, Canada, 1997.

[46] R. Hall. A system pathology of an organization: The rise and fall of the old Saturday Evening Post. Administrative Science quarterly, Vol. 21, 185-211, 1976.

[47] R. Hall. A framework linking intagible resource competitive avantage. Strategic management journal, Vol. 14, 607-618, 1993.

[48] É-M Hernandez. L'entrepreneuriat: Approche théoriques. Édition L'Harmattan, Paris, France, 2001.

[49] W. F. Hrebiniak, G. Joyce Lawrence. Organizational Adaptation: Strategic Choice and Environmental Determinism. Administrative Science quarterly, Vol. 30, 336-349, 1985 .

[50] H. C. Hsu Cathy, G. Z. Liu, S. Huang. , Acquiring Intangible Resources through Entrepreneurs' Network Ties: A Study of Chinese Economy Hotel Chains. Cornell Hospitality Quarterly, Vol. 56, No. 3, 273-284, 2015.

[51] G.T.M., Hult, D.J. Ketchen, S. F Slater. Market orientation and performance: An integration of disparate approaches. Strategic Management Journal, Vol. 26, 1173-1181, 2005.

[52] Itami, H. Mobilizing invisible assets. Cambridge, MA: Harvard University Press, USA, 1987.

[53] B. j. Jaworski, A. K. Kohli. Market orientation: Antecedents and consequences. Journal of Marketing, Vol. 57, 53-70, 1993.

[54] D. M. Johnson. Adaptation of organizational change models to the implementation of quality standard requirement. The International Journal of quality \& Reliability Management, Vol. 21, No. 2, 154-174, 2004.

[55] P-A. Julien. Qu'entend-on par PME. Les PME, bilan et perspectives. Economica, France, 23-35, 1994.

[56] M. Khalique, A. H. Bin Md. Isa. Intellectual Capital in SMEs Operating in Boutique Sector in Kuching, Malaysia. IUP Journal of Management Research, Vol. 13, No. 2, 2014.

[57] A. K. Kholi, B. J. Jaworski, Market orientation: The construct, research propositions and managerial implications. Journal of Marketing, Vol. 54, 1-18, 1990.

[58] S. Kiesler, L. Sproull. Managerial responses to changing environments: Perspectives on problem sensing from social cognition. Administrative Science quarterly, Vol. 27, 548-570, 1982.

[59] M. Kiggundu. Entrepreneurs and Entrepreneurship in Africa: What is known and what needs to be done. Journal of Developmental Entrepreneurship, Vol. 7, No. 3, 239-258, 2002.

[60] L. Konopielli, J. Bell. Reinventing aid for SMES in Eastern Europe: lessons from the implementation of the Struder program. Regional Studies; Vol. 32, No. 3, 1998.

[61] Y.-K. Kuo. Organizational commitment in an intense competition environment. Industrial Management \& Data Systems, Vol. 113, No. 1, 39-56, 2013.

[62] C. S. Lee, K. Y. Wong. Knowledge management performance measurement in micro-, small-, and medium-sized enterprises: An exploratory study. Business Information Review, Vol. 32, No 4. 204-211, 2015. 
[63] I. Lejárraga. Small and Medium-Sized Enterprises in Global Markets: A Differential Approach for Services?, OECD Trade Policy Papers, No. 165, OECD Publishing. 2014.

[64] L. C. Leonidou, C. S. Katsikeas, S. Samiee. Marketing strategy determinants of export performance: a meta-analysis. J. Bus. Res., Vol. 55, No. I, 51 -67, 2002.

[65] A.-B. Lily-Julienti, A. Hartini. Assessing the relationship between firm resources and product innovation performance: A resource-based view. Business Process Management Journal, Vol. 16, No. 3, 420-435, 2010.

[66] J. A. Mathews. Resource and activities are two sides of the same coin: duality of the activities and resource-based views of strategic management, paper presented at the Conference on Strategic Management, Copenhagen, 2006.

[67] M. McGreevy. Adaptive change in an evolving world of Work. Industrial and Commercial Training, Vol. 40, No. 7, 355-363, 2008.

[68] D. O. McKee, P. R Varadarajan, W. M. Pride. Strategic Adaptability and Firm Performance: A Market Contingent Perspective. Journal of Marketing, Vol. 53, 21-35, 1989.

[69] L. Mendes, L Ourenc,o. Factors that hinder quality improvement programs' implementation in SME. Journal of Small Business and Enterprise Development, Vol. 21 No. 4, 690-715, 2014.

[70] R. E. Miles, C. C. Snow, A. D Mayer, Jr. Coleman, J. Henry. Organizational Strategy, structure and process. Academy of Management Review, Vol. 3, pp. 596-562, 1978.

[71] D. Miller, P. H. Friesen. Strategy making and environment the third link. Strategic Management Journal, Vol. 4, 22-35, 1983.

[72] D. Miller, P. H. Friesen. Momentum and revolution in organization adaptation. Academy of Management journal, Vol. 23, 591-614, 1980.

[73] H. Mintzberg. Structure in 5's: A synthesis of the research in organization design. Management Science, Vol. 26, No. 3, 322-341, 1980.

[74] D. K. Mutalemwa. Does globalisation impact SME development in Africa? African Journal of Economic and Management Studies, Vol. 6, No. 2, 164-182, 2015.

[75] K. J. Muthoni, A. A. Ibrahim. The Role of Strategic Management Factors in Managing Growth of Small and Medium Enterprises- A Survey of Small and Medium Enterprises in Mombasa County. The International Journal of Business \& Management, Vol 4, No. 2, 2016.

[76] K. A. Nordstrom. Managez funky, vous aurez les meilleurs. Revue Management, Vol. 63, 122-125, 2000.

[77] A .O'Cass, P. Sok. The role of intellectual resources, product innovation capability, reputational resources and marketing capability combinations in firm growth. International Small Business Journal, Vol. 32, No. 8, 996-1018, 2014.

[78] J. Ojeda-Gomez, M. Simpson, S. C. L. Koh, J. Padmore. Achieving competitive advantage in the Mexican footwear industry Benchmarking, An International Journal, Vol. 14, No. 3, 289-305, 2007.

[79] C. Oliver. Strategic Responses to Institutional Processes.
Academy of Management Review, Vol. 16, No. 1, 145-179, 1991.

[80] B. Oyelaran-Oyeyinka, K. Lal. Institutional Support for Collective Learning: Cluster Development in Kenya and Ghana. African Development Review. Oxford, Vol. 18, No. $2 ; 2006$.

[81] J. Pfeffer, G. R. Salancik. The external control of organizations: A resource dependence perspective. New York: Harper and Row, 1978.

[82] J. Pope. Confronting Corruption: The Elements of National Integrity System. Transparency International, London, 2001.

[83] M. E Porter. Competitive Advantage: Creating and Sustaining Superior Performance., New York, NY: The Free Press, 1985.

[84] L.M. Puente, H. Rabbino. Creating value with strategic resources, online available at: www.iseesystems.com/community/connector/Zine/SeptOc t03/luz.html.

[85] W. A. Randolph, H. J. Sapienza, M. A. Watson Technology-Structure Fit and Performance in Small Businesses: An Examination of the Moderating Effects of Organizational States. Entrepreneurship Theory and Practice, Vol. 16, No. 1, 1991.

[86] G. Ray, J. B. Barney, W. A. Muhanna. Capabilities, business processes and competitive advantage: choosing the dependent variable in empirical test of resource-based view, Strategic Management Journal, Vol. 25, 23-37, 2004.

[87] R.F. Recardo. Overcoming resistance to change. National Productivity Review, Vol. 14, No. 2, 5-12, 1995.

[88] S. Robbins. Organizational behaviour: Concepts, controversies, applications (8th ed.). Upper Saddle River, NJ: Prentice Hall, 1998.

[89] J. Rojot. Théorie des organisations: Editions ESKA. Paris, France, 2005.

[90] M. Ruef. 1997. Assessing organizational fitness on a dynamic landscape: An empirical test of the relative inertia thesis. Strategic Management Journal, Vol. 18, 837-853, 2005.

[91] M. Schindehutte, M. Morris. Understanding strategic adaptation in small firms, International Journal of Entrepreneurial Behaviour and Research, Vol. 7, No. 3, 84-107, 2001.

[92] M. Sheehan. Human resource management and performance: Evidence from small and medium-sized firms. International Small Business Journal, Vol. 32, No 5. 545-570, 2014.

[93] G. Shirokova, I. Berezinets, A. Shatalov. Organisational change and firm growth in emerging economies. JEEMS, Vol. 19, No. 2, 185-212, 2014.

[94] N. Sinha, A K. Garg, N. Dhall. Effect of TQM principles on performance of Indian SMEs: the case of automotive supply chain, The TQM Journal, Vol. 28 No. 3, 338-359, 2016

[95] H. Song. Learning effective organizational strategies across culture: Leading change in Korean organizations. Peabody College of Vanderbilt University, Dissertation submitted in 
partial fulfillment of the requirements for the degree of Doctor of education, 2003.

[96] M .Stoica, M. Schindehute. Undestanding adaptation in small firms: links to culture and performance. Journal of Developmental Entrepreneurship, Vol. 4, No. 1, 1-15, 1999.

[97] J. .Storey. Focusing on how business changes affect individuals. People Management, Vol. 1, No. 8, 1995.

[98] D. J. Storey. Employment In D. J. Storey (td.), Understanding the small business sector, 160-203). Routldge, London, 1994.

[99] D. J Storey. Understanding the Small Business Sector, Thomson, Croatia, 1994,

[100] A. Sudolska, M. Chodorek. Resource dependence as the foundation for inter-firm relationships development and collaborative advantage. Economic and Social Development, 7th International Scientific Conference, New York City, 2014.

[101] T. Tambunan. Entrepreneurship Development: SME in Indonesia. Journal of Development Entrepreneurship, Vol. 12, No. 1, 2007.

[102] Z. Tian, T. Hafsi, W. Wu. 2009. Institutional Determinism and Political Strategies: An Empirical Investigation. Business Society; 48; 284 originally published online available http://bas.sagepub.com/cgi/content/refs/48/3/284

[103] P. R. Todd, R. Javalgi. Internationalization of SMEs in India; Fostering entrepreneurship by leveraging information technology, International. Journal of Emerging Markets. Bradford: Vol. 2, No. 2, 2007.

[104] D. Tolstoy. Differentiation in foreign business relationships: A study on small and medium-sized enterprises after their initial foreign market entry, International Small Business Journal 2014, Vol. 32, No. 1, 17 -35, 2014.

[105] S. Ulle Ravishankar, A. N. S. Kuma. Key Performance Indicators of TQM-An Analysis by Using Analytical Hierarchy Process. The International Journal of Business \& Management, Vol. 3, No. 8, 2015.

[106] P. Ussahawanitchakit. Administrative innovation, technical innovation, competitive advantage, competitive environment, and firm performance of electronics businesses in Thailand. Review of business research, Vol. 12, No. 1, 1-10, 2012.

[107] K. Warren. The softer side of strategy dynamics. Business Strategy Review, Vol. 11, 45-58, 2000.

[108] K. E. Weick. The social psychology of organizing. (2nd ed). Reading, MA: Addison-Wesley, 1979.

[109] L. S. Wiji Suratno. Improving the Performance of National Banking Business in Indonesia. International Journal of Innovations in Business. Vol. 2. No 5, 484-508, 2013.

[110] C. Y. Woo. A. C. Cooper, C. Nicholls-Nixon, W. C. Dunkelberg. Adaptation by start-up firms. In Churchill, N. C. et al. (Eds), Frontiers of Entrepreneurship Research, Babson College, Wellesley, MA, 306-19, 1990.

[111] Y. Xia, Y. Qiu, U. Zafar Ahmed. The Impact of Firm Resources on Subsidiary's Competitiveness in Emerging Markts: An empirical Study of Singaporean SMEs' performance in China. Multinational Business Review; Vol. 15, No. 2; 2007.

[112] S.-A. Zahra. The changing rules of global competitiveness in the 21st century, Academy of Management Executive, Vol. 13, 1999.

[113] M. M. El-Shobery, B. El-Iskandrani, M. Hegazy. Improving Organizational Performance of Small and Medium Enterprises in Egypt through Promoting the Human Factors in quality Management Systems. International Journal of Business and Management, Vol. 5, No. 6, 2010.

[114] R .Ackoff. The democratic corporation. New York: Oxford University Press, 1994.

[115] T Amburgery, K. Dawn, B. William. Resetting the clock: the dynamics of organizational change and failure. Administrative Science Quartely, Vol. 38, 51-73, 1993.

[116] P. Sherer, K. Lee. Institutional change in large law firms: A resource dependency and institutional perspective, Academy of Management Journal, Vol. 45, No. 1, 102-119, 2002.

[117] I. D. Coserin, V. C. Coserin, P. Coserin. The upsurge of hotels' strategic competition as per the E.U. integration, Global Conference on Business and Finance Proceedings, Vol. 7, No. 2, 633-637, 2012.

[118] P. Amadieu, V. Jean-Laurent. Intangible Effort and Performance: The Case of the French Wine Industry. Agribusiness, Vol. 26, No. 2, 280-306, 2010.

[119] B. J. Jaworski, A .Kohli, Market Orientation: Antecedents and Consequences. Journal of Marketing, Vol. 57, 53-70, 1993.

[120] E. J. Zajac, S. M. Shortell. Changing generic strategies: Likelihood, direction and performance implications, Strategic Management Journal, Vol. 10, 413-430, 1989.

[121] R. S Hassan, M. Hart. The determinants of small firm growth: an empirical study on Egyp. The Business and Management Review, Vol. 7, No. 2, 2016.

[122] A. Sánchez, Lago A, X. Ferràs., J. Ribera. Innovation Management Practices, Strategic Adaptation, and Business Results: Evidence from the Electronics Industry, J. Technol. Manag. Innov., Vol. 6, No. 2, 2011.

[123] D. HOLÁTOVÁ M BŘEZINOVÁ, P. ̌̌EHOŘ, V DOLEŽALOVÁ. Management of human resources in SMES: An Enterprise Odyssey. International Conference Proceedings. JEL Classification: M12, 2012.

[124] N. Sinha, A. Garg K,. N. Dhall. Effect of TQM principles on performance of Indian SMEs: the case of automotive supply chain. The TQM Journal, Vol. 28, No. 3, 338-359, 2016.

[125] M. Grimaldi, M. Greco, L. Cricelli. Perceived benefits and costs of intellectual capital in small family firms. Journal of Intellectual Capital, Vol. 17 No. 2, 351-372, 2016.

[126] F. Castilla-Polo, D Gallardo-Vázquez. The main topics of research on disclosures of intangible assets: a critical review, Accounting, Auditing \& Accountability Journal, Vol. 29, No. 2, $323-356,2016$. Permanent link to this document: http://dx.doi.org/10.1108/AAAJ-11-2014-1864. 